\title{
多結晶純銅の平面ひずみ圧縮塑性変形に伴う接触面のあれ*
}

\author{
邰 玉 柱*1, 阿 部 武 治*2, 清 水一 郎*3 \\ 川口順也*4, 納 所孝至*5

\section{Roughening of Contact Surface During Plane Strain Compressive Plastic Deformation of Polycrystalline Copper} \\ $\mathrm{Yu}^{-}$zhu TAI, Takeji ABE, Ichiro SHIMIZU, \\ Junya KAWAGUCHI and Takayoshi NOSHO

\begin{abstract}
Changes in surface roughness and three-dimensional microscopic shapes of contact surface of polycrystalline copper during plane strain compressive plastic deformation are studied. The roughening of contact surface is measured with a stylus instrument. The microscopic change in surface shape is also observed with a scanning electron microscope. The roughness of contact surface measured in the free direction is larger than that measured in the constrained direction for the specimen having transverse contact surface. Meanwhile, the roughness of contact surface measured in the loading direction of the specimen having longitudinal contact surface is a little larger than that measured in the free direction. From the observation by a scanning electron microscope, it is seen that the mountains and the valleys which appear on the free surface are sharp, while those on the contact surface are relatively rounded.
\end{abstract}

Key Words: Plasticity, Surface Roughening, Contact Surface, Plane Strain Compression, Polycrystalline Copper

\section{1. 緒言}

多結晶金属材料を塑性変形させると, 型や工具に接 触していない自由表面には表面あれが発生する。この 自由表面あれは，材料の微視的な不均一性と密接に関 係していることが指摘されておう，表面あれ形状の三 次元的測定や電子顕微鏡による結晶粒の変形挙動の観 察が行われている(1)-(4).

一方，多結晶金属相互の接触面においても，塑性変 形に伴って不均一変形が進行し, 表面あれが成長す $る^{(1)(5) \times 6)}$.この上うな接触面の微視的な形状変化は, 多結晶金属队部に打ける変形挙動の解明に有用である と考えられるほか，複合材料の界面特性，金属の接合 などとも関連する重要な研究課題であると考えられ る.

多結晡金属の接触面あれについて，先に著者らは，

* 原稿受付 1997 年5月21日

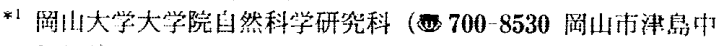
$311)$

*2 正員, 岡山大学 $T$ 学部.

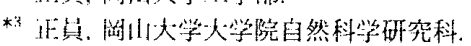

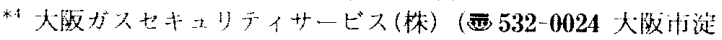

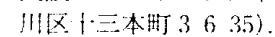

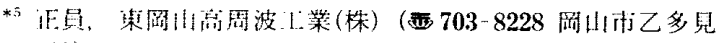
463).
工業用純銅の単軸圧縮に伴う自由表面および内部接触 面の表面粗さを測定し, 比較検討した(5)(6). その結果, 接触面におろいても負荷ひずみにほぼ比例して表面粗さ が堌加するが, その程度は自由表面の約半分と小さい こと，また電子顕微鏡観察から，接触面あれの形状は， 材料相互の拘束のために自由表面あれとは定性的に異 なることなどを指摘した. しかしながら一般の塑性加 エにおいては，材料が型や工具によって拘束されなが ら変形することから, 平面ひずみに近い状態で変形が 進行する場合も多い(7).このような平面ひずみ条件下 での接触面の変形挙動に関連した従来の矿究例として は, 人工的に作ったのこ状状の突起の变形挙動の観 察(8)などがあるが，接触面の微視的な表面形状变化に ついて調べた例は兒当たらない.

そこで本研究では，淔方体純銅を荷重垂直方向また は荷重方向に二分割した後, 再び重ね合わせた試験片 について，平面ひずみ压絔条件下における自由表面と 接触面の表面粗さの二次元的な変化を調べる．また， 接触面あれ形状を三次元的に測定することにより，平 面ひずみ条件下に打ける多結晶金属の内部接触面の微 視的変形挙動，および接触面に対与る荷重方向の影響 の解明を試みる。 


\section{2. 実 験 方 法}

\section{$2 \cdot 1$ 試験片および平面ひずみ圧縮試験＼cjkstart供試材} は工業用多結晶純銅 $(99.98 \mathrm{wt}$ \% \% Cu)である. 試験片 は，まず素材断面 $25 \times 25 \mathrm{~mm}$ の角棒から直方体に切 削加工後, マイクロカッタを用いて二分割した。次に 自由表面および接触面を, 研磨紙とバフ仕上げによっ て, 初期の中心線平均粗さ ${ }^{(9)}$ が $0.06 \mu \mathrm{m} R_{\mathrm{a}}$ 程度の鏡 面にした後, $600^{\circ} \mathrm{C}, 1$ 時間保持の真空焼なましを行つ て残留応力を除去した。なお，試験片は荷重方向に対 して平行に分割したものと、荷重垂直方向に分割した ものの 2 種類を作製した。平面ひずみ圧縮試験片の形 状と概略の寸法を図 1 に示す(ただし， $z$ 方向の寸法 は正確に $20 \mathrm{~mm}$ に仕上げている)。接触面および自 由表面に扔ける変形前の平均結晶粒径は，ともに約 75 $\mu \mathrm{m}$ であり，結晶粒形状はほほ等方性であった。

平面ひずみ理縮試験は，圧縮試験機 (東京衡機製 980 $\mathrm{kN}$ 形)に，図 2 に示すようなジグを取付けて行った。 な拉，ジグと試験片の間には，摩擦を低減するために テフロンシートを挟んでいる，試験片は，対数ひずみ で約-0.05の压縮ひずみを加えるごとに試験機から 取り外して, 自由表面あれと接触面あれを測定し, 最 終的にひずみが約 -0.60 まで変形させた。

$2 \cdot 2$ 表面あれの測定および電子顕微鏡観察 表 面粗さの測定には，触針式表面粗さ計(東京精密製サ ーフコム $304 \mathrm{~B}$ )を用いた。自由表面と接触面の二次 元的な表面粗さは, カットオフ值 $0.8 \mathrm{~mm}$, 測定長さ $8 \mathrm{~mm}$ の条件 ${ }^{(9)}$ で, 測定面内の直交する二方向につい て測定した、すなわち，図1に示すように，压縮方向 を $x$ 方向, ジグによって変形が拘束されている方向を $z$ 方向とすると，自由表面の場合は $x$ および $z$ 方向， 荷重方向に垂直な接触面の場合は $y$ および $z$ 方向, 荷 重力向に平行な接触面の場合は $x$ 抢よび $y$ 万向にお

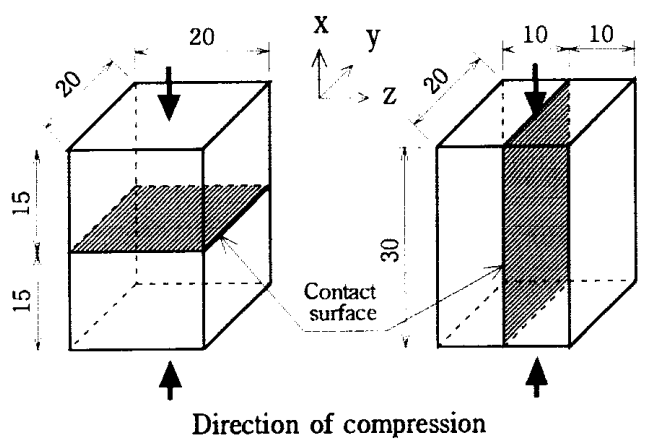

(a) Contact surface normal (b) Contact surface parallel to loading direction to loading direction
のおの 10 回測定し，最大值と最小值を除いた 8 回の 測定結果から平均値を求めた。

一方，接触面における三次元的な表面あれ形状につ いては，接触面内にけがき線で区別した $3 \times 3 \mathrm{~mm}^{2}$ の 領域を，カットオフなしで $10 \mu \mathrm{m}$ 間隔に約 300 回測定 し，著者らが開発した三次元表面あれ形状測定システ ム ${ }^{(4)}$ によって定量的に測定した。また, 走查形電子顕 微鏡 $(\mathrm{SEM}$ ，日立製 S-450 形)を用いて各ひずみ段階 での自由表面および接触面を観察し，それらの微視的 表面形状の変化に関しても定性的に検討を加えた。

\section{3. 実験結果および考察}

$3 \cdot 1$ 負荷ひずみに伴う表面粗さの変化 純銅試 験片を平面ひずみ条件下で圧縮し，自由表面および接 触面の二次元的な表面粗さを測定した。自由表面，荷 重方向に垂直な接触面, 荷重方向に平行な接触面のお のおのについて, 中心線平均粗さ (Centerline average roughness) $R_{a}$ おょび最大高さ(Maximum height) $R_{\max }$ と負荷ひずみ $\varepsilon$ の関係を図 $3 \sim 5$ に示す. 比較の ため，同じ純銅試験片の単軸圧縮の場合の，自由表面 および荷重方何に垂直な接触面の表面粗さの測定結 果(5)も図中に示している.

これらの測定結果から，自由表面と 2 種類の接触面 の二次元的な表面粗さは，ともにひずみにほほ比例し て増加するが，材料相互の拘束を受ける接触面粗さの 增加割合は，拘束されない自由表面よりも小さいこと がわかる.すなわち, 荷重方向に重直および平行な接 触面の粗さは，それぞれ自由表面の約 $2 / 5$ および約 2/7となっている.

自由表面に関しては，単軸圧縮の際には測定方向に よって表面粗さに差が認められなかったが(5), 平面ひ ずみ压縮においては, 荷重方向 ( $x$ 方向)に測定した粗 さのほうが拘束方向 $(z$ 方向) の粗さより $20 \%$ 程度大

Fig. 1 Compressive specimen

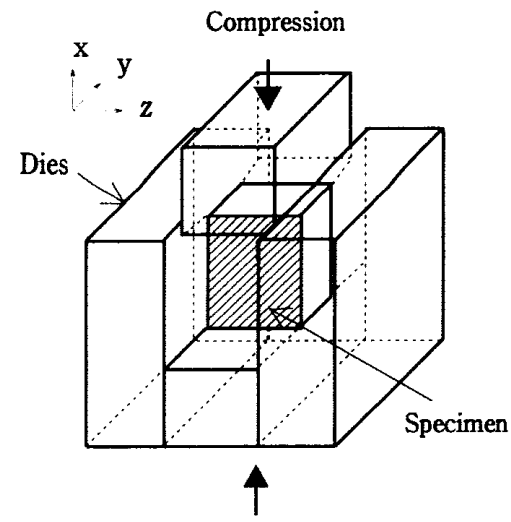

Fig. 2 Instrument for plane strain compression 
きくなる傾向がある(7). 一方, 荷重方向に垂直な接触 面においては, 自由変形方向 ( $y$ 方向)に測定した粗さ のほうが拘束方向 $(z$ 方向) よりも大きく, 荷重方向に 平行な接触面においては, 荷重方向 ( $x$ 方向)に測定し たほうが自由変形方向 ( $y$ 方向)よりも大きい.これら

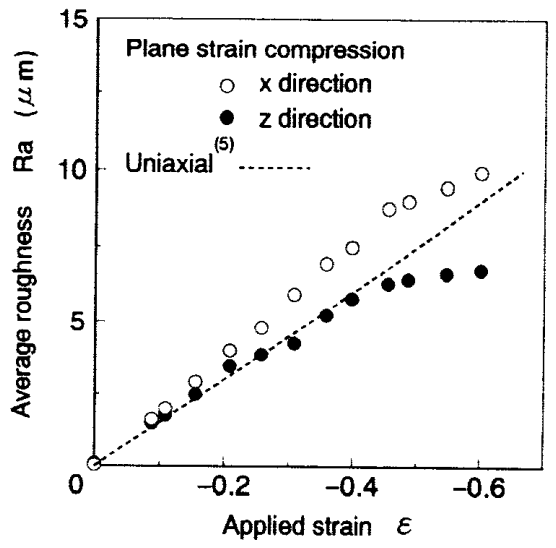

(a) Average roughness $R_{a}$
の測定方向による表面粗さの差は，後述する表面あれ 形状の性質に起因していると考えられる，各面におけ る粗さの増加割合は, 負荷ひずみ $\varepsilon=-0.40$ の近辺で 減少しているが,これは局所変形が生じたためと考え られる。また，図 5 に示すように, 荷重方向に平行な

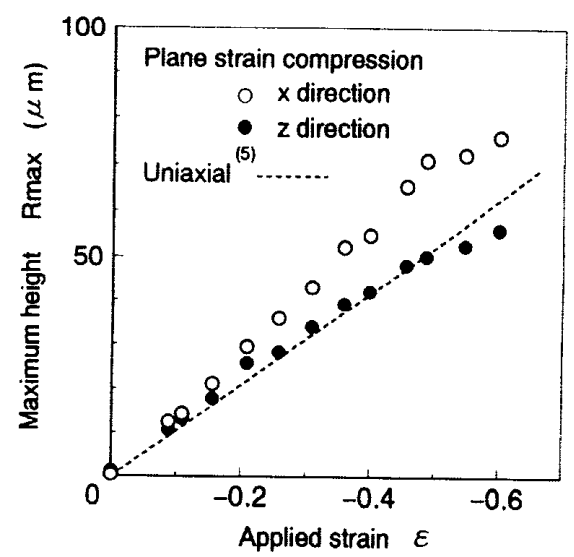

(b) Maximum height $R_{\max }$

Fig. 3 Change in centerline average roughness and maximum height with applied strain $\varepsilon$ on free surface

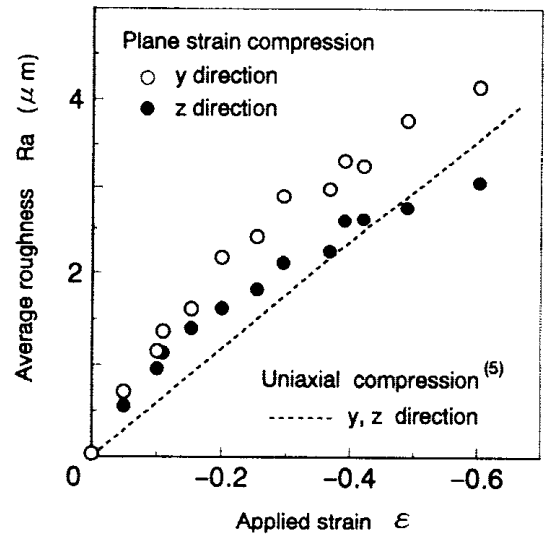

(a) Average roughness $R_{a}$

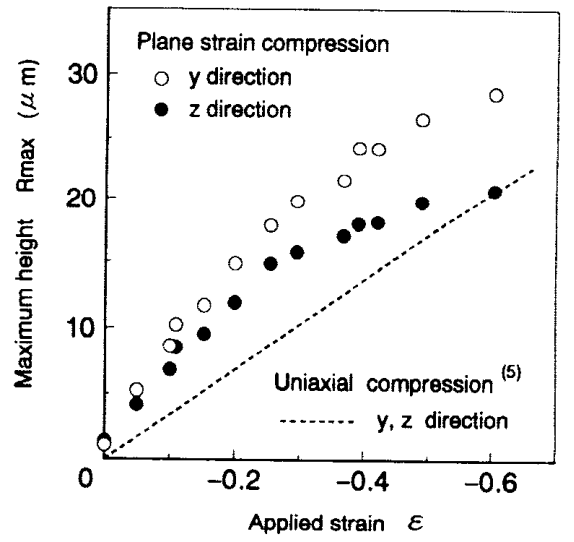

(b) Maximum height $R_{\max }$

Fig. 4 Change in centerline average roughness and maximum height with applied strain $\varepsilon$ on contact surface normal to loading direction

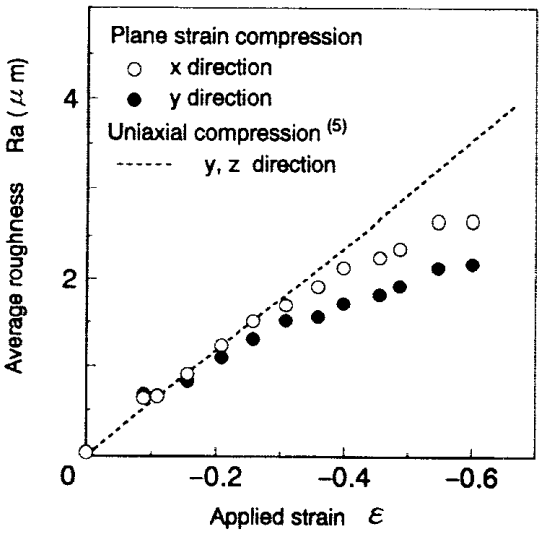

(a) Average roughness $R_{a}$

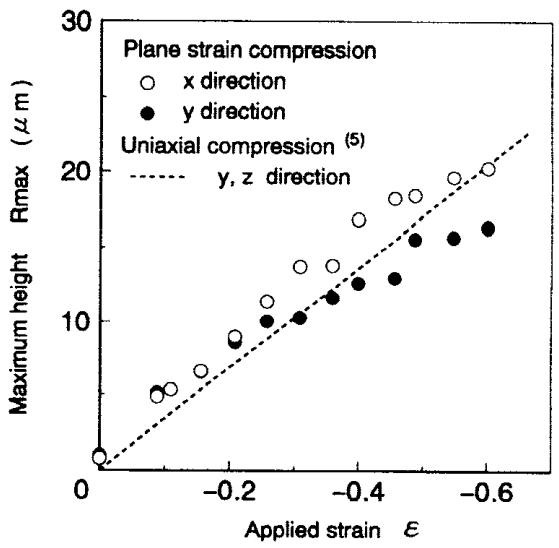

(b) Maximum height $R_{\max }$

Fig. 5 Change in centerline average roughness and maximum height with applied strain $\varepsilon$ on contact surface parallel to loading direction 
接触面においても，荷重方向 ( $x$ 方向)に単軸圧縮の場 合(破線) と同程度の表面粗さが生じていることは，z 方向の巨視的なひずみ $\varepsilon_{z}$ が零であるにもかかわらず, 微視的不均一変形を表している微視的ひずみ $\Delta \varepsilon_{z}$ は 単軸圧縮の場合とほほ同程度であることを示してお り, 興味樑い.

次に, 自由表面および接触面の表面粗さのバラツキ について検討するため, 先の報告 ${ }^{(6)}$ と同様に, 中心線 平均粗さ $R_{a}$ の標準偏差 $S$ (Standard deviation) と変 動係数 $V$ (Coefficient of variation)を求めたにこに, $V=S / \bar{R}_{a}, \bar{R}_{a}$ は平均值).図 6 はおのおのの面に対す る $R_{a}$ の標準偏差および変動係数と負荷ひずみの関係 を示している．いずれの面においても，中心線平均粗 さの標準偏差は負荷ひずみに対してほほ比例的に増加 するが, 他方, 変動係数はほほ一定值をとる。これら の傾向は，負荷ひずみが増加するとともに，材料の表 面だけでなく，その内部においても，材料不均質に起 因する微視的変形のバラツキが増大することを示して いると考えられる.

$3 \cdot 2$ 接触面粗さの变化に対する平面ひずみ圧縮の 变形形態の影響 $3 \cdot 1$ 節で述べたように, 平面ひず み圧縮条件下における各測定面の表面粗さは，負荷ひ
ずみ $\varepsilon=-0.40$ の付近で表面粗さの増加割合が減少す る。そこで, 平面ひずみ圧縮における試験片の変形形 態を調べるために，試験片とジグが接する側面に $1 \mathrm{~mm}$ 間隔でけがき線を描き，各負荷ひずみ段階にお けるけがき線の変形を観察した。そ結果の一例を図 7 に示す。平面ひずみ生縮条件下においては，負荷ひ ずみが約ー 0.40 から試験片とジグの接する面にせん 断変形の集中寸る領域が現れ, 試験片の変形形態(微 視的なひずみ分布)が変化することがわかる。このせ 几断変形の集中領域は，図 8(b)に模式的に示すよう な方向に発生している，すなわち，負荷ひずみが約 -0.40 以降においては，このような領域に変形が集中 し，それ以外の各測定領域における変形量が負荷ひず みに対して小さくなったために，平均的な粗さの増加 割合も低下したものと考えられる。

\section{$3 \cdot 3$ 負荷ひずみに伴う接触面の微視的形状変化}

平面ひずみ条件下における接触面の三次元的な表面 あれ形状の変化の様子を図 9,10 に示す。すなお 図 9，10は，それぞれ荷重方向に垂直な接触面抢よび 荷重方向に平行な接触面の等高線図と三次元表示の例 を示しているなお，等高線図には表面あれの高さを 8 等分して示している。また，図 9(a), 図10(a)に
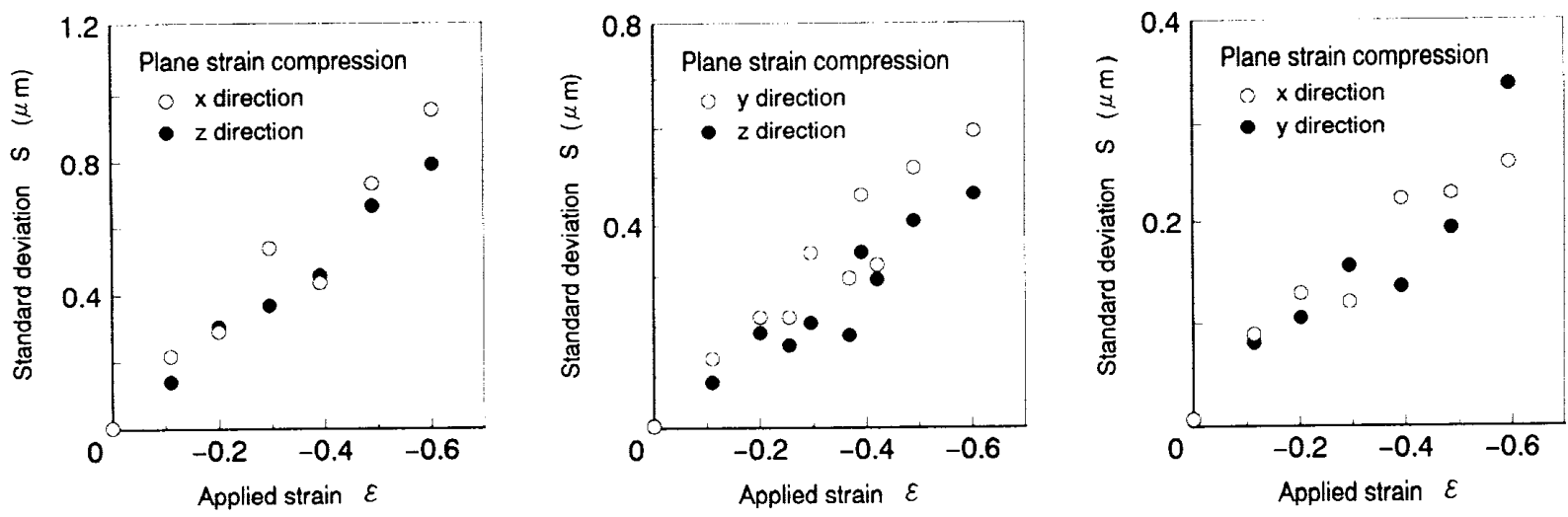

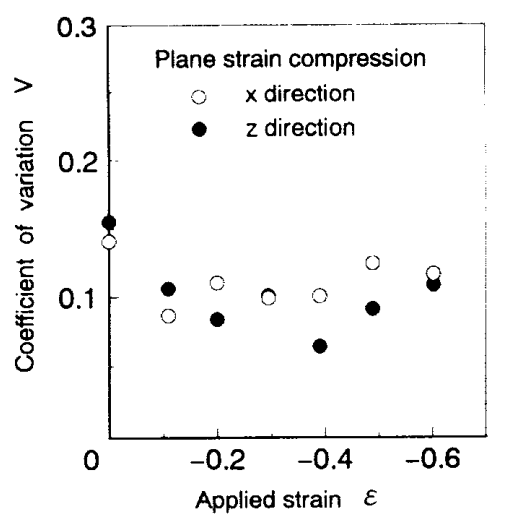

(a) Free surface

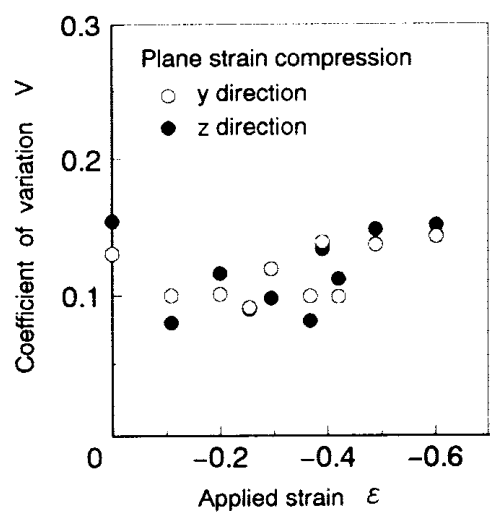

(b) Contact surface normal to loading direction

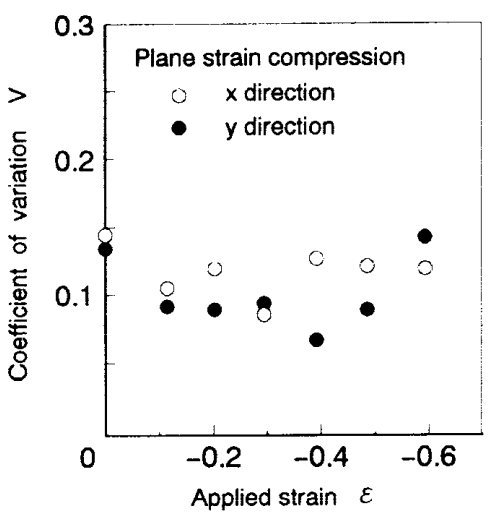

(c) Contact surface parallel to loading direction

Fig. 6 Standard deviation $S$ and coefficient of variation $V$ of centerline average roughness $R_{a}$ versus applied strain $\varepsilon$ for various surface 
示す左右の図は，それぞれ互いに接触する二つの面の 測定結果である。これらの左右の図を比較すると，互 いに接触している二つの面の微視的な山凸は，反転し た形状となっており，負荷ひずみに伴って互いの位置 関係を維持しながら成長していることがうかる。

図 9 に示す接触面あれの凹凸は負荷ひずみの増加に 伴って成長している，荷重方向に垂直な接触面におい ては, 塑性変形の比較的初期において, 接触面あれの 山や谷が拘束方向 $(z$ 方向)に連なるように形成され， 負荷ひずみが増加しても，その形状はほぼ維持されな がら高低差が増加している。一方，図 10 に示す荷重

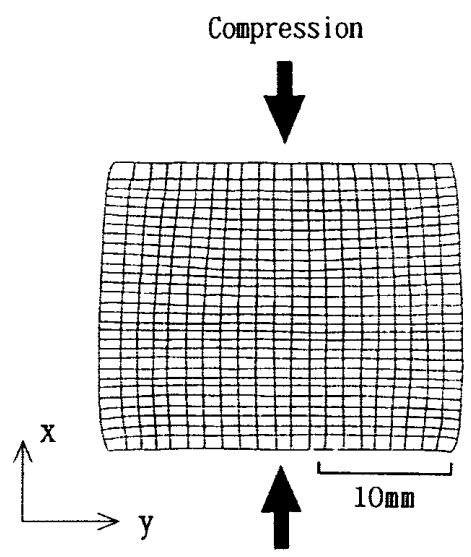

(a) Applied strain $\varepsilon=-0.30$

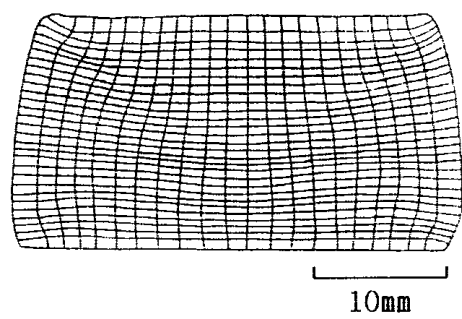

(b) Applied strain $\varepsilon=-0.50$

Fig. 7 Deformation pattern of constrained surface for plane strain compression
方向に平行な接触面では，接触面あれの山や谷は自由 変形方向 $(y$ 方向)に連なるように形成される。これら の傾向が，図 4,5に极いて示した測定方向による表面 粗さの差の原因となっていると考えられる. 一方, 平 面ひずみ圧縮の際の自由表面では，拘束方向 $(z$ 方向) に長い山や谷が観察されている(7).これらの結果に基 ー゙いて, 平面ひずみ压縮変形に伴う微視的な不均一変 形による山脈の形成方向を模式的に示すと, 図 8(a) のようになる。

図 11 に, 自由表面, 荷重方向に垂直な接触面および 荷重方向に平行な接触面の電子顕微鏡観察結果の一例 $(\varepsilon=-0.30)$ を示す.これらの結果を比較すると, 自 由表面では，すべり带の発達による表面の山凸が明り ように認められるのに対して，接触面では，すべり帯 も現れているがその量は自由表面より少なく，それら の四凹も先端が押し潰されて滑らかになっていること がわかる，この傾问は，接触面の才们にかかおらずほ 涩同様である。

以上のような実験結果から，多結晶金属の平面ひず み压維に対寸る変形モードを推定すると次のようにな ると考えられる。すなうち，巨視的には，z方向の変 形が拘束されるため, 図 8 (b)に示すように $x^{-} y$ 平面 内の変形は, $\mathrm{AC}, \mathrm{BD}$ 方向のせん断変形が生じきすく なり, 結果として自由表面や荷重方向に垂直な接触面 では $z$ 万向に山脈が形成され [図 $9(\mathrm{~b})], y$ 方向に 测定した表面粗さが $z$ 方向より大きくなるものと考 えられる(図 4)。こ机刘して $x-z$ 平面内の変形は， 図 8(c)に示すように，z方向の拘束のため $\varepsilon_{z}=0$ で あり，EG，あるいは $\mathrm{FH}$ 万向のせん断変形は巨視的に は起こらない。しかし，微視的にはこのような変形も 生じていると考えられ，図5に示与ように，微視的ひ ずみ $\Delta \varepsilon_{z} \neq 0$ となるものと考えられる。したがって， 荷重方向の接触面では主として $y$ 方向に山脈が形成

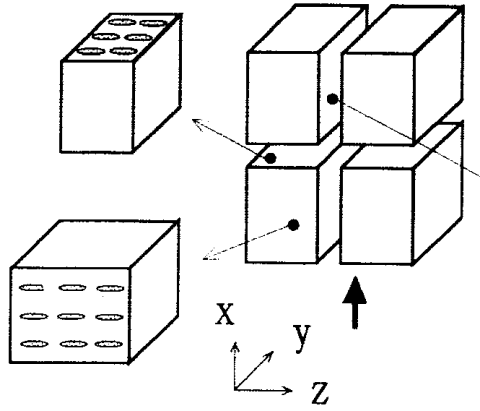

(a) Direction of microscopic mountains

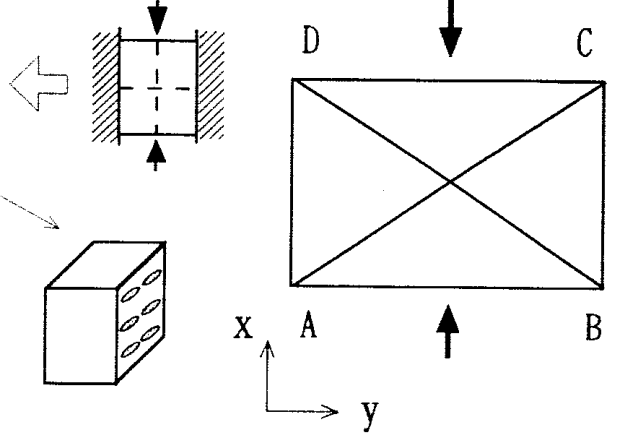

(b) $x-y$ plane

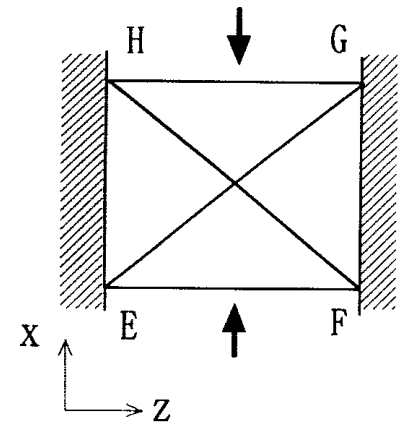

(c) $x$ z plane

Fig. 8 Schematic diagram of macroscopic and microscopic deformation mode under plane strain compression 
され [図 $10(\mathrm{~b})]$ ，図 5 に示すように $x$ 方向の粗さ が $y$ 方向より大きくなったものと考えられる。しか しながら,この場合には, 変形は $y$ 方向にも生じるた め, 変形はよりランダムとなる.また, 端面, 側面で 摩擦がないものと仮定した場合には, 塑性力学におけ るレービー・ミーゼスの式から予測されるように, $\sigma_{z}=\sigma_{x} / 2$ となることから, 測定方向による表面粗さの 差異も, 荷重方向に垂直な接触面（図 4) と比較して荷 重方向に平行な接触面 (図 5)のほうが小さくなったも のと考えられる.

なお今後, 本研究の延長として, 圧延などの具体的 な塑性加工過程における内部接触面の粗さの変化につ
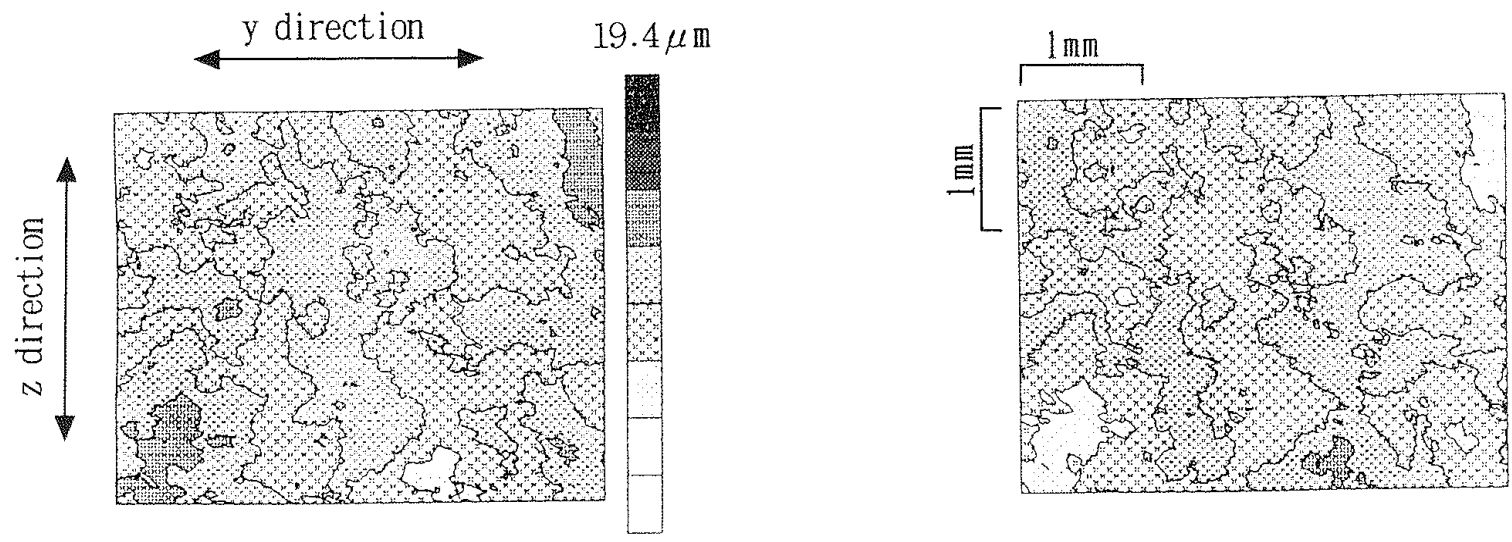

$-18.0 \mu \mathrm{m}$

Applicd strain $\varepsilon=-0.10$.

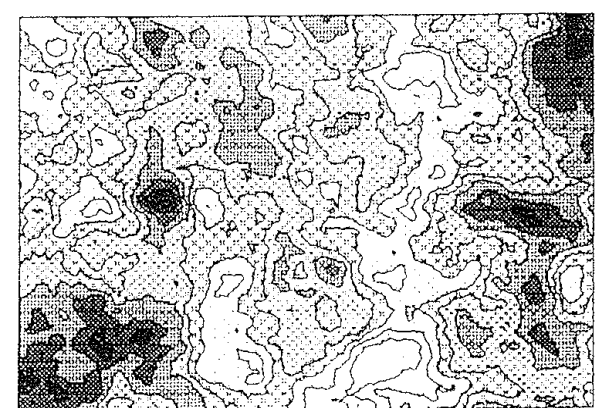

Upper
Applied strain $\varepsilon=-0.30$.

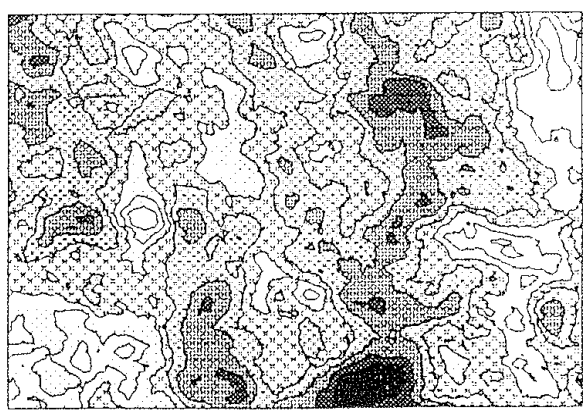

Lower

(a) Contour map for upper and lower contact surface

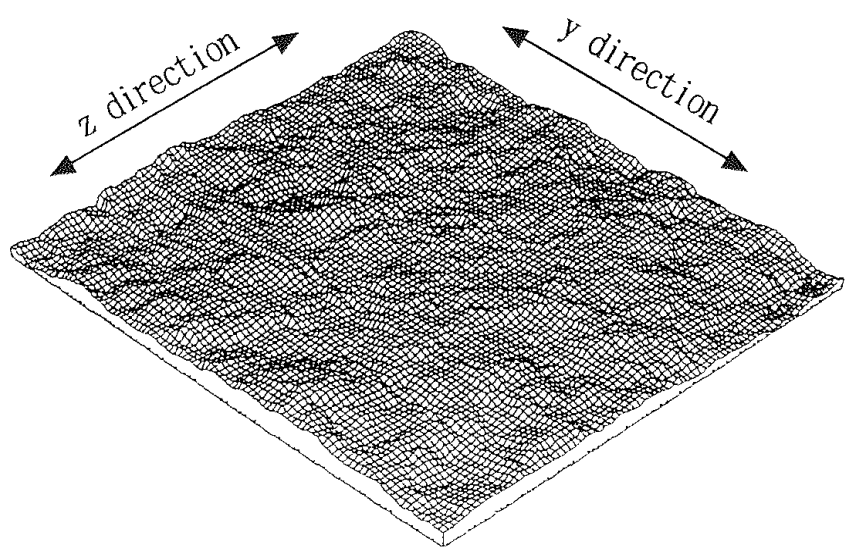

Applicd strain $\varepsilon=-0.10$

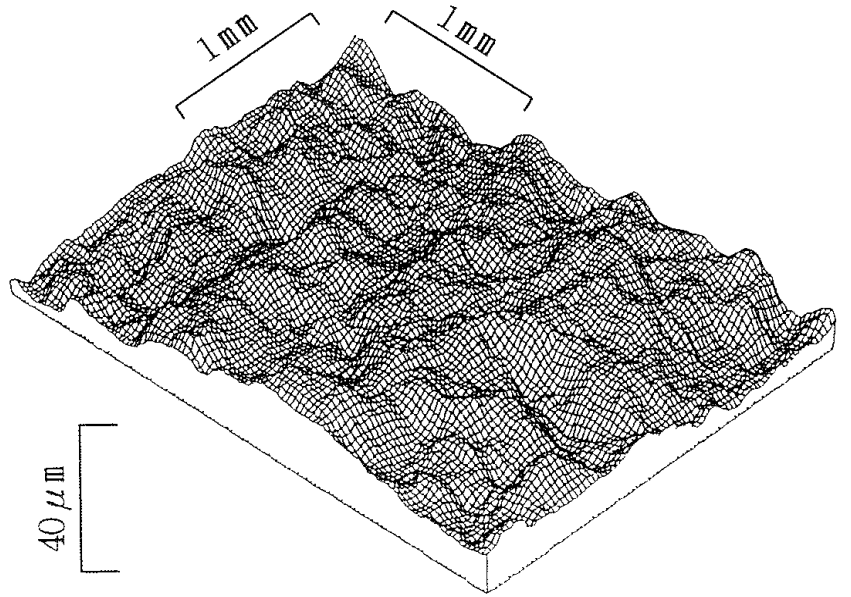

Applicd strain $\varepsilon=-0.30$.

(b) Shape of roughened surface for lower contact surface

Fig. 9 Three-dimensional shape of roughened surface for plane strain compression (contact surface normal to loading direction) 
いても調べる予定である。

\section{4. 結言}

多結晶純銅の直方体形状誠験片を用い, 荷重方向に 垂直または平行に二分割し，分割面を再び重ね合わせ て平面ひずみ圧縮試験を行った，各試験片の自由表面 と 2 種類の接触面について, 二次元表面粗さおよび三 次元表面あれ形状の変化を調べるとともに, 走查形電
子顕微鏡による観察を行い，表面における微視的不均 一変形について検討した，得られた主な結果を要約す ると次のとおりである。

（1）平面ひずみ告縮における自由表面, 荷重方向 に垂直な接触面おうよび荷重方向に平行な接触面の粗さ は，ともに負荷ひずみにほほ比例して増加するが，接 触面の粗さは自由表面より小さく, 自由表面の約 $2 / 5 \sim 2 / 7$ 倍となる。
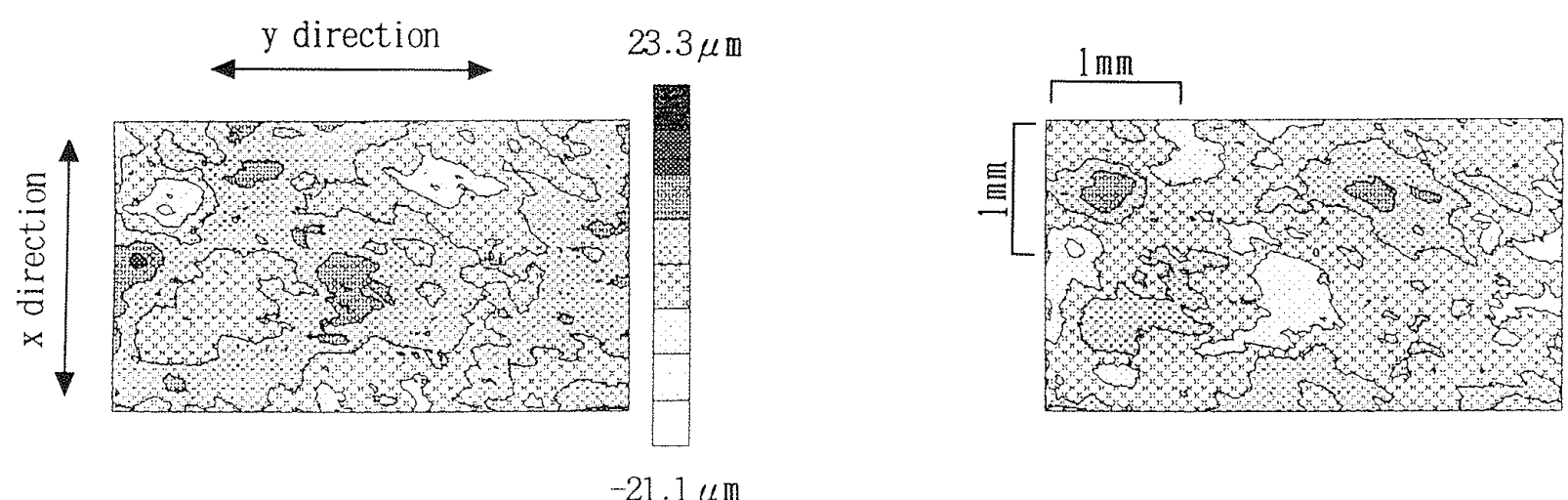

$-21.1 \mu \mathrm{m}$

Applied strain $\varepsilon=-\cdots-0.30$
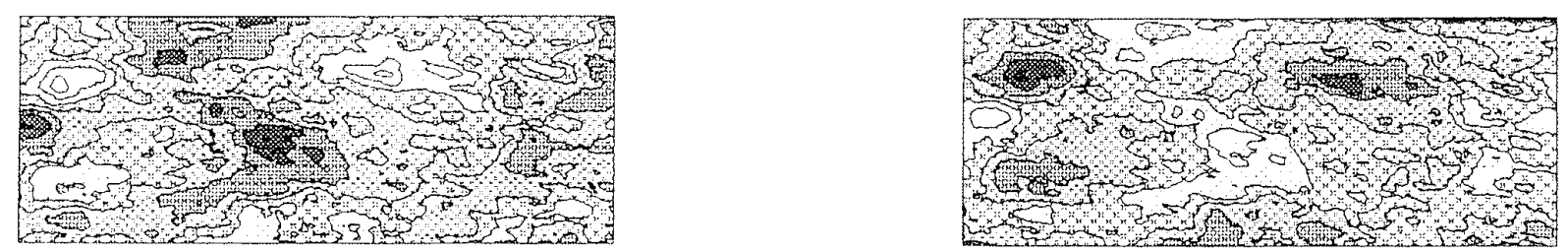

Right

Applied strain $\varepsilon=-0.50$.

Left

(a) Contour map for left and right contact surface

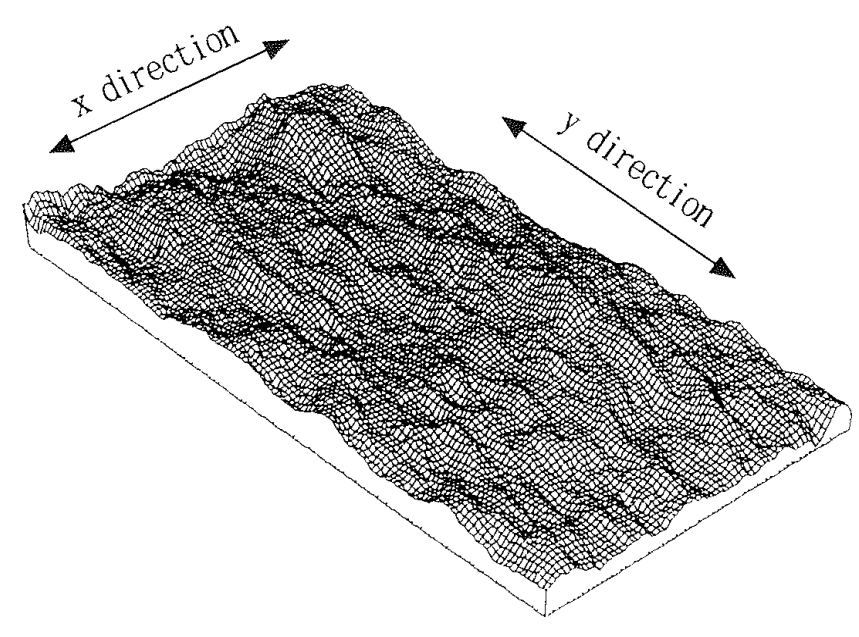

Applicd strain $\varepsilon=-0.30$

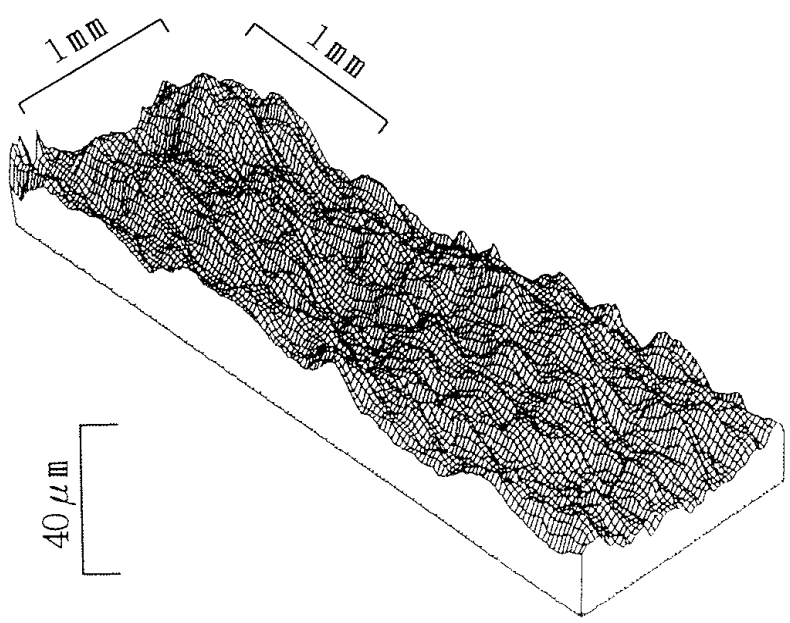

Applicd strain $\varepsilon=-0.50$.

(b) Shape of roughened surface for right contact surface

Fig. 10 Three-dimensional shape of roughened surface of plane strain compression (contact surface parallel to loading direction) 


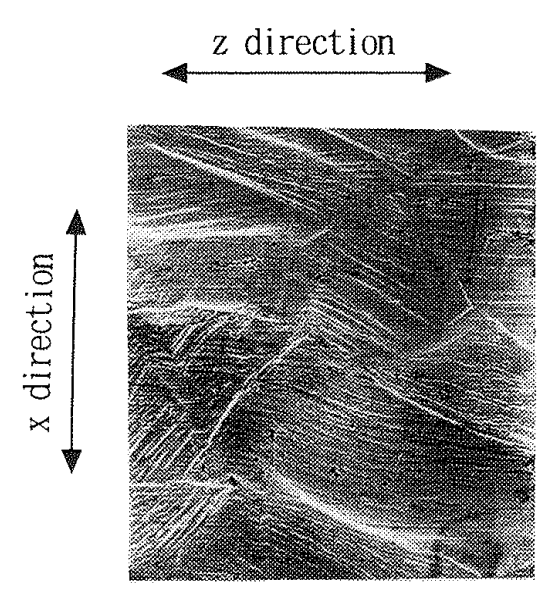

(a) Free surface

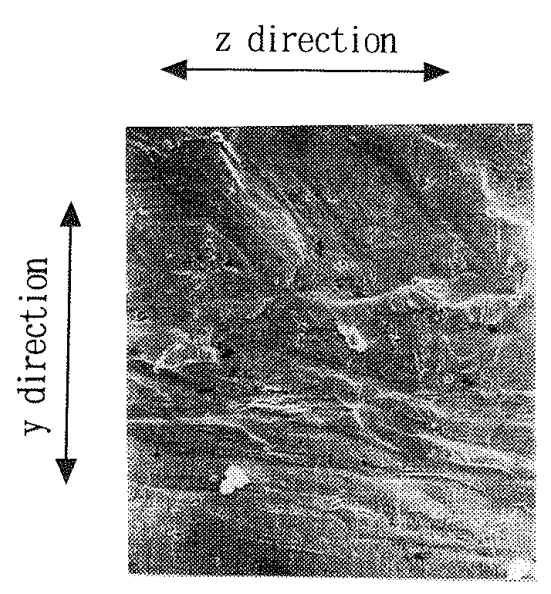

(b) Contact surface normal to loading direction

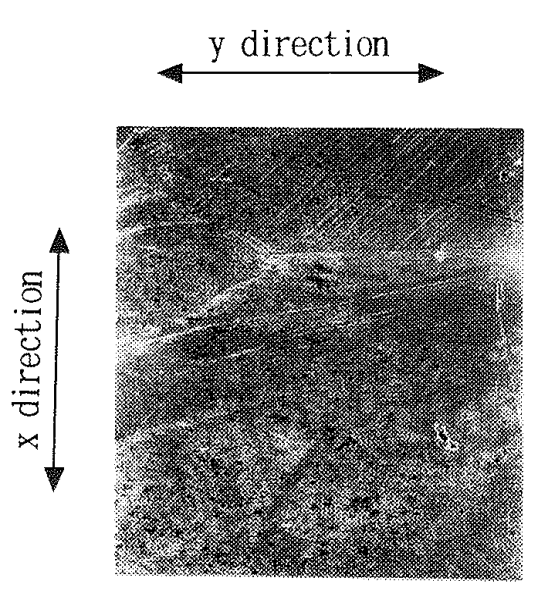

(c) Contact surface parallel to loading direction

Fig. 11 Examples of SEM micrographs of free surface and contact surface $(\varepsilon=-0.30)$

（2）自由表面における表面粗さは，拘束方向に測 定した粗さよりも, 荷重方向に測定した表面粗さのほ うが約 20\%大きくなる.一方, 荷重方向に垂直な接触 面においては自由変形方向に測定した粗さが大きく, 荷重方向に平行な接触面においては荷重方向に測定し た粗さが大きくなる。

（3）接触面の粗さの増加は, 圧縮負荷ひずみ $-0.30 \sim-0.40$ 程度で低下する傾向が認められた。 これは, 平面ひずみ圧縮変形において, せん断変形の 集中域が生じるためであると考えられる，また，荷重 方向に垂直な接触面の粗さは, 荷重方向に平行な接触 面より約 30\%大きくなった. 一方, 荷重方向に平行な 接触面では，巨視的には面に垂直な方向のひずみを生 じていないにもかかわらず, 微視的には不均一変形を 生じていることが示された。

（4）接触面の表面あれ形状は, 負荷ひずみの増加 に伴って最初に生じた凹凹の位置関係をほほ維持しな がら成長する. 荷重方向に垂直な接触面の微視的な山 と谷は, 拘束方向に長く伸びているのに対して, 荷重 方向に平行な接触面の山と谷は, 自由変形方向に長く のびる.これらの材料内部における微視的流れ方向の
異方性を考えることによって, 平面ひずみ圧縮条件下 の接触面のあれの変化の傾向を, 統一的に説明するこ とができる.

（5）走查電子顕微鏡観察により，接触面において も自由表面と同様に凹凸の起伏および結晶粒内のすべ り変形が認められたが，それらは変形が相互に拘束さ れるために自由表面よりも緩やかな形状をしているこ とが認められた。

\section{文献}

（1）小坂田宏造 - 大矢根守哉, 機論, 36-286(1970), 1017-1022.

(2) Thomas, T. R. 編, Rough Surfaces, (1982), Longman.

（3）阿部武治・清水一郎・西山大洋, 機論, 57-542, A (1991), 2587-2594.

（4）清水一郎 - 阿部武治, 機論, 60-578, A (1994), 2369-2376.

（5）阿部武治・邰玉柱・松崎稔・清水一郎, 機論, 61-587, A (1995), 1562-1567.

（6）邰玉柱・阿部武治・清水一郎 - 納所孝至, 機論, 62-604, A (1996), 2770-2276.

（7）納所孝至・清水一郎・阿部武治・若山正宏・堤健二郎, 材料, 46-8(1997), 887-892.

(8) Gotoh, M., Yamashita, M. and Torii, N., JSME Int. J., Ser. A, 36-2 (1993), 182-189.

（9）日本工業規格 B 0601-1982. 